Check for updates

Cite this: RSC Adv., 2017, 7, 27007

Received 13th February 2017

Accepted 26th April 2017

DOI: $10.1039 / c 7 r a 01782 k$

rsc.li/rsc-advances

\section{Simultaneous bacterial inactivation and degradation of an emerging pollutant under visible light by $\mathrm{ZnFe}_{2} \mathrm{O}_{4}$ co-modified with $\mathrm{Ag}$ and $\mathrm{rGO} \uparrow$}

\begin{abstract}
Nirina Khadgi, Akhanda Raj Upreti and Yi Li*
Herein, we investigated the simultaneous photoinactivation of $E$. coli and degradation of an endocrine disrupting compound, $17 \alpha$-ethinyl estradiol (EE2), by the $\mathrm{ZnFe}_{2} \mathrm{O}_{4}-\mathrm{Ag} / \mathrm{rGO}$ nanocomposite. In a pure bacterial suspension, inactivation of $\log 7.2$ was achieved in $60 \mathrm{~min}$ with $250 \mathrm{mg} \mathrm{\textrm {L } ^ { - 1 }}$ loading of $\mathrm{ZnFe}_{2} \mathrm{O}_{4}-\mathrm{Ag} / \mathrm{rGO}$; however, when EE2 was present in the suspension, complete inactivation of the bacteria was achieved only after $210 \mathrm{~min}$ of treatment with a $500 \mathrm{mg} \mathrm{L}^{-1}$ loading of $\mathrm{ZnFe}_{2} \mathrm{O}_{4}-\mathrm{Ag} / \mathrm{rGO}$. Results obtained from the bacterial membrane injury test, SEM, FTIR, and antioxidant enzyme activities indicated that resilience of $E$. coli decreased against the oxidative stress induced by the photocatalyst, outstripping the bacterial defense mechanism and subsequently decomposing the constituent macromolecules, ultimately causing bacterial inactivation. Scavenging experiment for different active species indicated that $\mathrm{H}_{2} \mathrm{O}_{2}$ played the most important role for bacterial inactivation and $\mathrm{OH}^{\cdot}$ played the most important role for EE2 degradation, showing that the roles of the active species were dissimilar for microbial inactivation and organic pollutant degradation. Bacterial inactivation was significantly affected by the presence of EE2. Thus, the antibacterial study of the photocatalysts in this system needs to be carried out with more specificity.
\end{abstract}

\section{Introduction}

Globally, 2 billion people drink water from contaminated sources, causing half a million deaths due to water-borne diseases each year. ${ }^{1}$ Providing safe drinking water via efficient water disinfection processes is important to improve public health. Along with pathogens, different pollutants that are not degraded via conventional treatments remain undetected in water. These recalcitrant pollutants are termed emerging pollutants due to not only their increasing occurrence and awareness related to ecological consequences but also lack of guidelines for them. ${ }^{2,3}$ The occurrence of emerging pollutants is expected to increase with our changing lifestyle. Their continual administration although in low concentration can cause different adverse effects, such as endocrine disruption that causes reproductive and sexual abnormalities, to aquatic and terrestrial ecosystems including humans. ${ }^{4}$

Water disinfection is mainly achieved via processes such as chlorination or ozonation in water treatment plants. The main concern regarding these processes is the formation of potentially carcinogenic disinfection by-products. ${ }^{5-7}$ In developing

Key Laboratory of Integrated Regulation and Resource Development on ShallowLakes, Ministry of Education, College of Environment, Hohai University, Nanjing, 210098, PR China.E-mail:envly@hhu.edu.cn; nirina@hhu.edu.cn

$\dagger$ Electronic supplementary information (ESI) available. See DOI: 10.1039/c7ra01782k countries where water treatment facilities are not well developed, solar disinfection (SODIS) is also a popular method for disinfecting water in the home. ${ }^{8}$ However, long irradiation time required for the SODIS acts as a bottleneck for the process during times of increased demand. ${ }^{9}$

Photocatalysis has been found to be effective for the degradation of hazardous compounds as well as disinfection of bacteria and viruses in the presence of light. ${ }^{10}$ To date, $\mathrm{TiO}_{2}$ is the most preferred photocatalyst due to its stability and lowcost; however, the band gap of $>3.2 \mathrm{eV}$ limits its activity in the UV region, comprising only $4 \%$ of the solar spectrum. ${ }^{11}$ Recovery of the catalysts is another issue concerning the safety of the ecosystem and reuse of the catalysts. ${ }^{12,13}$ Therefore, development of visible light active and easily separable magnetic photocatalysts is in its full pace to prevent environmental contamination, maximize the efficiency, and ensure the sustainability of photocatalysis. ${ }^{\mathbf{1 4}}$

Water treatment deals with different types of pollutants, such as organic, inorganic, and biological pollutants, and their simultaneous interactions. However, most of the studies reported for the photocatalytic treatment of water deal with the treatment of one or similar pollutants at a time. ${ }^{10,15}$ Tahir et al., 2016, investigated the photodegradation and inactivation of methylene blue and bacteria. ${ }^{16}$ Similarly, $\mathrm{Ng}$ et al., 2016, studied the bactericidal ability of magnetic photocatalysts for Gramnegative (E. coli) and Gram-positive (S. aureus) bacteria. ${ }^{17}$ Both these studies were carried out in a single component system. 
There are relatively few studies that deal with the simultaneous processing of different pollutant types and their detailed investigation. Pablos et al., 2012, investigated inactivation of $E$. coli and pharmaceutical oxidation with $\mathrm{TiO}_{2}$ under UV irradiation. Philippe et al., 2016, studied photocatalytic disinfection in the presence of an emerging contaminant using an innovative solar simulator with respect to osmotic and mechanical stress. ${ }^{18}$ Pablos et al., 2012, investigated the inactivation of E. coli and pharmaceutical oxidation with $\mathrm{TiO}_{2}$ under UV irradiation. ${ }^{19}$

In our previous study, we synthesized a $\mathrm{ZnFe}_{2} \mathrm{O}_{4}-\mathrm{Ag} / \mathrm{rGO}$ nanocomposite (NC) using a facile template or surfactant-free method, ${ }^{20}$ and the photocatalytic activity of the NC was assessed by the degradation of $17 \alpha$-ethinyl estradiol (EE2), an endocrine disrupting compound (EDC), as the model of an emerging pollutant in the presence of humic acid. Zinc ferrite $\left(\mathrm{ZnFe}_{2} \mathrm{O}_{4}\right)$ is a visible-light active magnetic spinel ferrite semiconductor with a band gap of $\sim 1.9 \mathrm{eV}$. However, it suffers from the limitations of low photoelectric efficiency and rapid charge recombination. ${ }^{21}$ Addition of $\mathrm{Ag}$ nanoparticles (NPs) and rGO to bare $\mathrm{ZnFe}_{2} \mathrm{O}_{4}$ had a synergistic effect, leading to the decreased aggregation of the NPs, increased surface area, better absorption in the visible region, and effective electron-hole generation transfer, resulting in better photocatalytic activity. ${ }^{\mathbf{2 0}}$

In this study, we simultaneously investigated the $\mathrm{ZnFe}_{2} \mathrm{O}_{4}-$ $\mathrm{Ag} / \mathrm{rGO} \mathrm{NC}$ for its bactericidal effect and degradation of an emerging pollutant in a single system and attempted to differentiate the antibacterial activities exhibited by the $\mathrm{ZnFe}_{2} \mathrm{O}_{4}-\mathrm{Ag}$ / rGO nanocomposite in the presence of EE2. Moreover, bacterial cell injury, morphology distortion, and changes in cell substances during the treatment and enzymatic assay were carried out to gain insights into the bacterial inactivation mechanism, and different scavenging experiments were carried out to determine the roles played by the active species in both the inactivation and degradation processes.

\section{Experimental}

\section{Synthesis of the $\mathrm{ZnFe}_{2} \mathrm{O}_{4}-\mathrm{Ag}-\mathrm{rGO}$ nanocomposite}

First graphite oxide (GO) suspension was prepared by mixing 20 mg GO powder previously, prepared by Hummers and Offeman method $^{62}$ in $60 \mathrm{~mL}$ ethanol under sonication for $1 \mathrm{~h}$. Then, another $20 \mathrm{~mL}$ of ethanol was added to achieve $1 \mathrm{mM}$ concentration. $\mathrm{Zn}\left(\mathrm{NO}_{3}\right)_{2} \cdot 6 \mathrm{H}_{2} \mathrm{O}, 2 \mathrm{mM} \mathrm{Fe}\left(\mathrm{NO}_{3}\right)_{3} \cdot 9 \mathrm{H}_{2} \mathrm{O}$, and $0.05 \mathrm{mM}$ $\mathrm{AgNO}_{3}$ were added under magnetic stirring for $30 \mathrm{~min}$. The obtained reddish brown solution was added into the GO suspension and stirred for another $2 \mathrm{~h}$. Then, the mixture was poured into a Teflon-lined stainless steel autoclave and reacted at $180{ }^{\circ} \mathrm{C}$ for $12 \mathrm{~h}$. After being cooled, $\mathrm{ZnFe}_{2} \mathrm{O}_{4}-\mathrm{Ag} / \mathrm{rGO}$ nanocomposite was washed several times with distilled water and dried in an oven at $60{ }^{\circ} \mathrm{C}$ for $12 \mathrm{~h}$.

\section{Characterization}

Scanning electron microscopy (SEM, Hitachi S-4800), diffuse reflectance spectroscopy (JASCO V-670), energy-dispersion X-ray analysis (EDAX PV 9100), and X-ray photoelectron spectroscopy (XPS) were performed using ESCA PHI 5000C. X-ray diffraction analysis (Bruker AXS, Germany) and photoluminescence (PL) spectroscopy (Hitachi F-7000) were conducted to analyze the synthesized nanocomposites.

\section{Photocatalytic procedure}

E. coli and EE2 were chosen as the model for a water-borne bacteria and an emerging pollutant with endocrine disrupting properties, respectively. E. coli, freshly grown in Luria Bertani (LB) broth (10 g tryptone, $5 \mathrm{~g}$ yeast extract, and $10 \mathrm{~g} \mathrm{NaCl}$ per litre) and incubated overnight at $37{ }^{\circ} \mathrm{C}$ under aerobic conditions with constant shaking was used for the photocatalytic inactivation experiments. Before each experiment, a 10000 -fold dilution of the bacterial stock solution was carried out using a $0.9 \% \mathrm{NaCl}$ solution. The initial bacterial population was in the range between $10^{7}$ and $10^{8} \mathrm{CFU} \mathrm{mL}{ }^{-1}$. The suspension was stirred in the dark for 1 hour to attain the equilibrium. For simultaneous photocatalytic degradation and bacterial inactivation, the bacterial suspension was added to the previously prepared EE2 solution $\left(2 \mathrm{mg} \mathrm{L}^{-1}\right)$ under continual stirring to prevent its recrystallization. The photocatalyst was dispersed in the suspension under continuous stirring. The solution was irradiated by a $300 \mathrm{~W}$ Xe lamp, and a cut-off filter was used to cut the radiation to $<400 \mathrm{~nm}$. The samples were withdrawn for enumeration of bacteria and measurement of the EE2 concentration at different time intervals. The concentration of EE2 was determined by high-performance liquid chromatography (HPLC) measurement using an Agilent 1260 series fluorescence detector at an excitation wavelength of $280 \mathrm{~nm}$ and an emission wavelength of $310 \mathrm{~nm}$, as mentioned elsewhere. ${ }^{22}$ The minimum detection limits (MDL) were $0.01 \mathrm{mg}$ $\mathrm{L}^{-1}$ as inferred by the lowest standard solution detected.

The bacterial viability was performed by the plate counting method. Samples were withdrawn at different times of the experiment, and after appropriate dilution, $100 \mu \mathrm{L}$ of the sample was used to plate onto the LB agar plate and was incubated for $18 \mathrm{~h}$ at $37^{\circ} \mathrm{C}$. Herein, three replicate plates were used at each sampling time.

\section{Determination of the damages to bacterial permeability}

Injury caused by damage to the outer membrane was identified via comparing bacterial cultivability using a non-selective LB medium and selective LB medium supplemented by $10 \mathrm{~g} \mathrm{~L}^{-1}$ Na-cholate as reported by Dunlop et al. (2015). ${ }^{23}$ Samples were withdrawn at different treatment times, spread onto both media after appropriate dilutions, and then incubated at $37^{\circ} \mathrm{C}$ for $24 \mathrm{~h}$ before bacterial counting. The injury was calculated as follows:

$$
\text { Injury }(\%)=((\text { total }- \text { non-injured }) / \text { total }) \times 100
$$

where total and non-injured represent the concentration of bacteria in the non-selective and the selective LB medium, respectively (measured in $\mathrm{CFU} \mathrm{mL}^{-1}$ ).

\section{Scanning electron microscopy (SEM) and Fourier transform infrared (FTIR) spectroscopy analyses of the bacterial sample}

The bacterial samples were harvested by centrifuging at different times of the experiment. Then, the bacteria were fixed 
with $2.5 \%$ glutaraldehyde solution for 2 hours and washed with DI water. Samples were then dehydrated with the increasing concentrations of an ethanol solution (30, 50, 70, 80, 90, and $100 \%$ ) and dried overnight at $35{ }^{\circ} \mathrm{C}$. For FTIR, bacterial samples before and after the treatment were harvested via centrifugation and dried at $30{ }^{\circ} \mathrm{C}$ for $24 \mathrm{~h}$. The FTIR analysis was performed using $\mathrm{KBr}$ discs and finely ground bacterial samples and $\mathrm{KBr}$ in the ratio of $1: 50$, analyzed using a Varian 300 FTIR in the wavenumber region of $4000-400 \mathrm{~cm}^{-1}$ at $2 \mathrm{~cm}^{-1}$ spectral resolution.

\section{Intracellular enzymatic assay}

The bacterial density of $10^{9}$ was used for the enzyme assay. Herein, four $\mathrm{mL}$ of the sample was withdrawn and centrifuged at $10000 \mathrm{rpm}$ for $5 \mathrm{~min}$. The cells were re-suspended in $2 \mathrm{~mL}$ phosphate-buffered saline (PBS) solution and sonicated for $1 \mathrm{~min}$ at $40 \mathrm{kHz}$ frequency at $4{ }^{\circ} \mathrm{C}$ and again centrifuged at $10000 \mathrm{rpm}$ for $5 \mathrm{~min}$. Supernatant was obtained for the measurement of protein, superoxide dismutase (SOD), and catalase (CAT). The enzyme activity was calculated as per mg of protein.

Protein concentration in the cell extracts was determined using the Bradford Coomassie-binding colorimetric method. ${ }^{24,25}$ Protein concentrations were estimated by measuring the absorbance at $595 \mathrm{~nm}$, obtained for a series of standard protein dilutions using bovine serum albumin (BSA). SOD activity was measured via the water soluble nitroblue tetrazolium method using an SOD WST-1 (A001-3) assay kit, and the CAT activity was determined via a visible-light method using a Catalase assay kit (A007-1) obtained from Nanjing Jiancheng Technology Co. Ltd.

\section{Active species analysis}

To elucidate the role of the active species in the photocatalytic mechanism, a series of experiments was conducted using different scavengers to remove their corresponding active species and analyze their contribution in the E. coli inactivation and EE2 degradation. Isopropanol $\left(0.5 \mathrm{mmol} \mathrm{L}^{-1}\right)$, potassium dichromate $\left(0.05 \mathrm{mmol} \mathrm{L}^{-1}\right)$, EDTA $\left(0.1 \mathrm{mmol} \mathrm{L}^{-1}\right)$, ascorbic acid $\left(0.5 \mathrm{mmol} \mathrm{L}^{-1}\right)$, and catalase $\left(3000 \mathrm{U} \mathrm{mL}^{-1}\right)$ were used for scavenging $\mathrm{OH}^{\cdot}$, electron $\left(\mathrm{e}^{-}\right)$, hole $\left(\mathrm{h}^{+}\right), \mathrm{O}_{2}{ }^{\cdot-}$, and $\mathrm{H}_{2} \mathrm{O}_{2}$, respectively. The concentrations were based on the preliminary experimental data to maximize the scavenging effect and minimize the bactericidal effect.

Terephthalic acid probe method, nitroblue tetrazolium assay, and titanium(Iv) oxysulfate (modified method DIN38402H15) method were used to identify the generation of $\mathrm{OH}^{\cdot}, \mathrm{O}_{2}{ }^{\cdot-}$, and $\mathrm{H}_{2} \mathrm{O}_{2}$, respectively, and understand the photocatalytic mechanism.

\section{Results and discussion}

\section{Characterizations}

Scanning electron microscopy images of different nanocomposites (NC) are illustrated in Fig. 1 for comparison. $\mathrm{ZnFe}_{2} \mathrm{O}_{4}$ nanoparticles (NP) are highly aggregated and form clusters ranging from 50 to $100 \mathrm{~nm}$, as seen in Fig. 1(a).
However, aggregation was greatly reduced in the presence of graphene sheets in $\mathrm{ZnFe}_{2} \mathrm{O}_{4} / \mathrm{rGO}$ and $\mathrm{ZnFe}_{2} \mathrm{O}_{4}-\mathrm{Ag} / \mathrm{rGO} \mathrm{NCs},{ }^{26}$ as seen in Fig. 1(b) and (c), respectively. The EDAX measurement also confirms the presence of $\mathrm{Zn}, \mathrm{Fe}, \mathrm{O}, \mathrm{C}$, and $\mathrm{Ag}$ elements (Fig. 1(d)).

$\mathrm{X}$-ray diffraction spectra of $\mathrm{GO}, \mathrm{rGO}, \mathrm{ZnFe}_{2} \mathrm{O}_{4}, \mathrm{ZnFe}_{2} \mathrm{O}_{4} / \mathrm{rGO}$, and $\mathrm{ZnFe}_{2} \mathrm{O}_{4}-\mathrm{Ag} / \mathrm{rGO}$ are shown in Fig. $\mathrm{S} 1 . \dagger$ The characteristic (001) peak at $10.5^{\circ}$, as shown in Fig. S1(a), $\dagger$ represents highly oxidized and interconnecting GO layers as the result of the oxidation process. The disappearance of the (001) peak, as shown in Fig. S1(a), $\dagger$ and appearance of a broad peak (002) at $\sim 24^{\circ}$, as seen in Fig. S1(b), $\dagger$ suggest distorted stacking of graphene sheets due to the removal of oxygen-containing functional groups during the hydrothermal reduction of GO. However, the presence of $\mathrm{ZnFe}_{2} \mathrm{O}_{4}$ and $\mathrm{Ag}$ NPs prevents the aggregation of the graphene sheets, as seen in the SEM and TEM images; ${ }^{27}$ Fig. S1(b) $\dagger$ suggests the exfoliation and reduction of GO during the hydrothermal reaction. ${ }^{28}$ The main peaks observed at $30^{\circ}, 35.5^{\circ}, 43^{\circ}, 53.5^{\circ}, 56.7^{\circ}$, and $62.4^{\circ}$, as shown in Fig. S1(c)-(e), $\dagger$ correspond to the crystal planes of the cubic spinel $\mathrm{ZnFe}_{2} \mathrm{O}_{4}$ (JCPDS no. 77-0011), and peaks at $38.1^{\circ}, 44.2^{\circ}$, $64.4^{\circ}$, and $77.4^{\circ}$, as shown in Fig. S1(e), $\dagger$ correspond to the facecentered cubic (FCC) structure of Ag (JCPDS card no. 07$0783) .^{29,30}$

To study the oxidation state of the elements of $\mathrm{ZnFe}_{2} \mathrm{O}_{4}-\mathrm{Ag}$ / rGO, XPS was performed. Fig. $\mathrm{S} 2 \uparrow$ shows the high resolution XPS of $\mathrm{Zn} \mathrm{2p,} \mathrm{Fe} \mathrm{2p,} \mathrm{O} \mathrm{3d,} \mathrm{and} \mathrm{Ag} \mathrm{3d} \mathrm{present} \mathrm{in} \mathrm{the} \mathrm{ZnFe}_{2} \mathrm{O}_{4}-\mathrm{Ag} /$ rGO nanocomposite. In Fig. S2(a), $\dagger$ the binding energies of $\mathrm{Zn}$ $2 \mathrm{p}_{1 / 2}$ and $\mathrm{Zn} 2 \mathrm{p}_{3 / 2}$ appearing at 1044.9 and $1022.2 \mathrm{eV}$ can be attributed to the +2 oxidation state of $\mathrm{Zn}^{29}$ The two distinct peaks at 725.3 and $711.5 \mathrm{eV}$ correspond to $\mathrm{Fe} 2 \mathrm{p}_{1 / 2}$ and $\mathrm{Fe} 2 \mathrm{p}_{3 / 2}$, respectively, and a satellite peak at $719.4 \mathrm{eV}$ in Fig. S2(b) $\dagger$ is characteristic of Fe with a +3 oxidation state. ${ }^{31}$ The $\mathrm{Ag} 3 \mathrm{~d}_{5 / 2}$ and $\mathrm{Ag} 3 \mathrm{~d}_{3 / 2}$ peaks at 368.1 and $374.1 \mathrm{eV}$ binding energies indicate the presence of zero-valent Ag, as seen in Fig. S2(c). $\dagger^{32}$ The deconvoluted peaks of $\mathrm{C} 1 \mathrm{~s}$ at the binding energies of 284.6, 285.5, 287.3, and $288.7 \mathrm{eV}$, as shown in Fig. S2(d), $\dagger$ are related to $\mathrm{C}=\mathrm{C}-\mathrm{C}, \mathrm{C}-\mathrm{OH}, \mathrm{C}-\mathrm{O}-\mathrm{C}$, and $\mathrm{C}=\mathrm{O}$, respectively. ${ }^{31}$ The higher intensity of the $\mathrm{sp}^{2}$ hybridized $\mathrm{C}=\mathrm{C}-\mathrm{C}$ atoms compared to that of the oxygenated functional groups indicates the reduction of GO during the formation of the $\mathrm{ZnFe}_{2} \mathrm{O}_{4}-\mathrm{Ag} / \mathrm{rGO}$ nanocomposite, ${ }^{33}$ which is in agreement with the XRD measurement results.

The UV-visible diffuse reflectance spectra for $\mathrm{ZnFe}_{2} \mathrm{O}_{4}$, $\mathrm{ZnFe}_{2} \mathrm{O}_{4} / \mathrm{rGO}$, and $\mathrm{ZnFe}_{2} \mathrm{O}_{4}-\mathrm{Ag} / \mathrm{rGO}$ were obtained to analyze their optical behavior (Fig. S3 $\dagger$ ). As shown in Fig. S3(a), $\dagger$ $\mathrm{ZnFe}_{2} \mathrm{O}_{4}$ shows absorption in the visible light due to its narrow band gap. ${ }^{34}$ However, with the successive addition of GO and $\mathrm{Ag}$, the absorption greatly strengthens in the visible region due to the introduction of a continuous absorption band from $\mathrm{GO}^{35}$ and surface plasmon resonance (SPR) of the $\mathrm{Ag}$ nanoparticle, ${ }^{36}$ as shown in Fig. S3(c) and (d). $\uparrow$ The characteristic absorption spectrum of $\mathrm{Ag}$ around $410 \mathrm{~nm}$ in the case of $\mathrm{ZnFe}_{2} \mathrm{O}_{4}-\mathrm{Ag} / \mathrm{rGO}$ is not prominent due to low concentration of $\mathrm{Ag}(0.05 \mathrm{mM}) .{ }^{29}$ The photoluminescence (PL) spectra of $\mathrm{ZnFe}_{2} \mathrm{O}_{4}, \mathrm{ZnFe}_{2} \mathrm{O}_{4} / \mathrm{rGO}$, and $\mathrm{ZnFe}_{2} \mathrm{O}_{4}-\mathrm{Ag} / \mathrm{rGO}$ NCs are shown in Fig. 2. The emission peak observed around $460-490 \mathrm{~nm}$ in the PL spectra of $\mathrm{ZnFe}_{2} \mathrm{O}_{4}$ is 

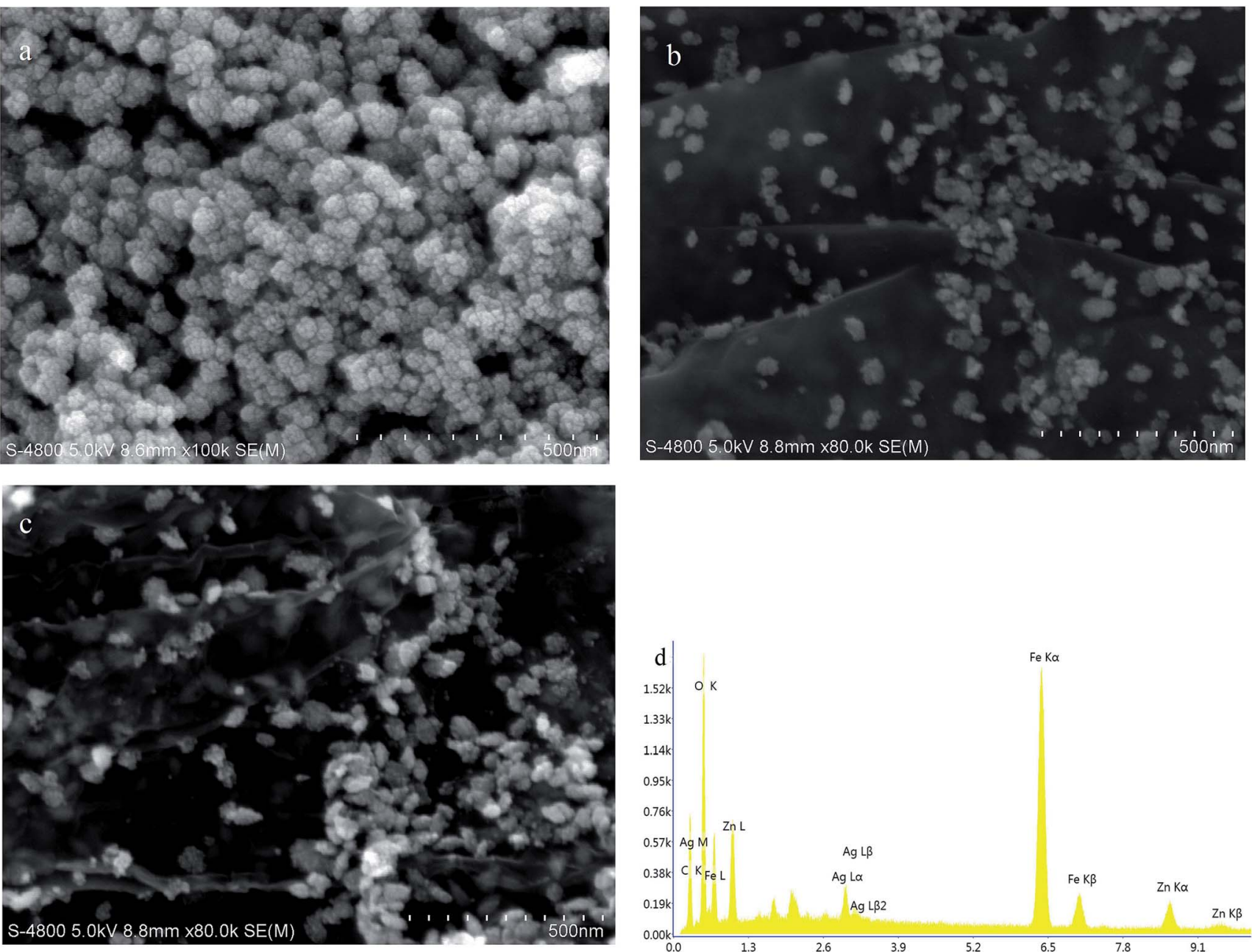

Fig. 1 SEM images of (a) $\mathrm{ZnFe}_{2} \mathrm{O}_{4}$, (b) $\mathrm{ZnFe}_{2} \mathrm{O}_{4} / \mathrm{rGO}$, (c) $\mathrm{ZnFe}_{2} \mathrm{O}_{4}-\mathrm{Ag} / \mathrm{rGO}$, and (d) $\mathrm{EDAX}$ of $\mathrm{ZnFe}_{2} \mathrm{O}_{4}-\mathrm{Ag} / \mathrm{rGO}$

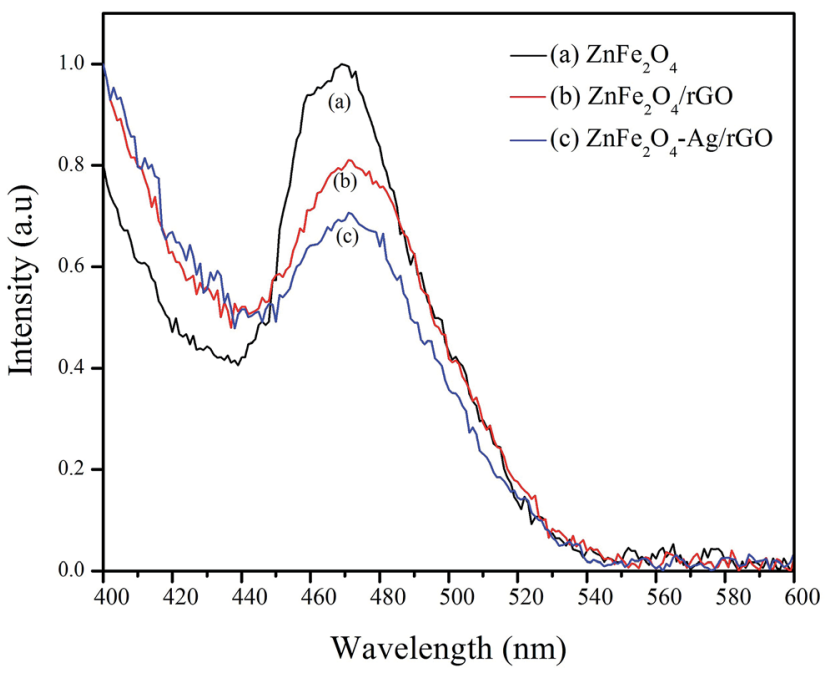

Fig. 2 Photoluminescence spectra of $\mathrm{ZnFe}_{2} \mathrm{O}_{4}, \mathrm{ZnFe}_{2} \mathrm{O}_{4} / \mathrm{rGO}$, and $\mathrm{ZnFe}_{2} \mathrm{O}_{4}-\mathrm{Ag} / \mathrm{rGO} \mathrm{NCs}$. attributed to the recombination of a photogenerated electronhole pair. The decrease in the intensity of the peak in the case of $\mathrm{ZnFe}_{2} \mathrm{O}_{4} / \mathrm{rGO}$ and $\mathrm{ZnFe}_{2} \mathrm{O}_{4}-\mathrm{Ag} / \mathrm{rGO}$ NCs is due to the suppression of the electron-hole recombination due to the presence of rGO and Ag NPs. Graphene sheets have excellent electronic conductivity, and Ag NPs act as the electron sink, leading to an effective separation of the electron-hole pair, which helps to prolong their lifetime and increase the photocatalytic efficiency. ${ }^{35,37}$

\section{Photocatalytic performance}

Photocatalytic inactivation of $\boldsymbol{E}$. coli. The light and dark control experiments were performed to determine the effect of light and catalyst alone on the bacterial population. As shown in Fig. 3, the light control showed no bactericidal effect, which suggested that no photolysis of bacterial cells occurred under the visible light irradiation. However, there was marked reduction in the bacterial population in the presence of photocatalysts. The $\log$ reduction of $2.7,3.7$, and 7.5 was achieved in the presence of $\mathrm{ZnFe}_{2} \mathrm{O}_{4}, \mathrm{ZnFe}_{2} \mathrm{O}_{4} / \mathrm{rGO}$, and $\mathrm{ZnFe}_{2} \mathrm{O}_{4}-\mathrm{Ag} / \mathrm{rGO}$ in $60 \mathrm{~min}$, respectively. The complete inactivation of bacteria in 


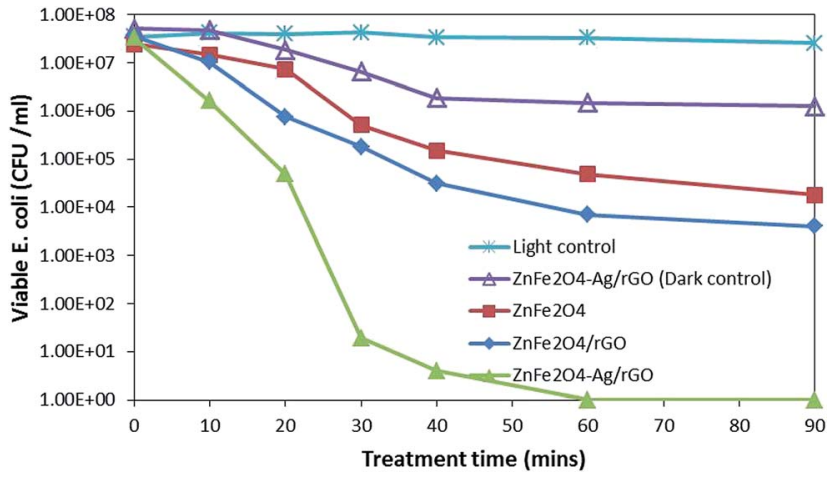

Fig. 3 E. coli inactivation during the photocatalytic treatment with different catalysts.

60 min by $\mathrm{ZnFe}_{2} \mathrm{O}_{4}-\mathrm{Ag} / \mathrm{rGO} \mathrm{NC}$ clearly demonstrates enhanced inactivation compared to that by $\mathrm{ZnFe}_{2} \mathrm{O}_{4}$ and $\mathrm{ZnFe}_{2} \mathrm{O}_{4} / \mathrm{rGO}$. A dark control experiment with the $\mathrm{ZnFe}_{2} \mathrm{O}_{4}-\mathrm{Ag} / \mathrm{rGO} \mathrm{NC}$ was also carried out to distinguish the bacterial inactivation caused by the physical contact from that caused by the photocatalytic process. ${ }^{38}$ The log reduction of only 1.5 in 60 min during the dark control experiment clearly states that the bacterial inactivation is actually a photocatalytic process and not just due to physical contact with NC. The enhanced photocatalytic properties of $\mathrm{ZnFe}_{2} \mathrm{O}_{4}-\mathrm{Ag} / \mathrm{rGO}$ as compared to those of $\mathrm{ZnFe}_{2} \mathrm{O}_{4}$ and $\mathrm{ZnFe}_{2} \mathrm{O}_{4} / \mathrm{rGO}$ can be attributed to the increased surface area and better charge generation and separation due to the presence of rGO and Ag NPs. ${ }^{39-41}$ Furthermore, the concentration of $\mathrm{Ag}$ in the treated water was measured using inductively coupled plasma-optical emission spectrometry (ICP-OES). The concentration of the residual $\mathrm{Ag}$ is found to be $0.003 \mathrm{mg} \mathrm{L}^{-1}$ for the catalyst loading of $500 \mathrm{mg} \mathrm{\textrm {L } ^ { - 1 }}$ (optimal loading), which is considered safe for human consumption according to the WHO guidelines for drinking water. ${ }^{42}$

Simultaneous bacterial inactivation and degradation of the emerging pollutant. Simultaneous bacterial inactivation and degradation of the emerging pollutant was carried out by inoculating the bacterial suspension into the previously prepared EE2 solution $\left(2 \mathrm{mg} \mathrm{L}^{-1}\right)$. The optimal catalyst loading for the bacterial inactivation was found to be $250 \mathrm{mg} \mathrm{L}^{-1}$, less than $500 \mathrm{mg} \mathrm{L}^{-1}$ for EE2 degradation (Fig. S4 $\dagger$ ). The decrease in the photocatalytic efficiency with the loading of $1000 \mathrm{mg} \mathrm{L}^{-1}$ can be attributed to the light shielding effect of the catalyst and reduced surface area exposed to the light as well as the pollutants. ${ }^{43}$ The photocatalytic degradation of the EE2 solution alone and changes in the UV-vis absorption spectra during the degradation process are shown in Fig. S5 and S6, $\dagger$ respectively. To study the simultaneous EE2 degradation and E. coli inactivation, we carried out experiments with both loadings and studied how the optimal loadings of different systems affected the performance during the simultaneous inactivation and degradation. As seen in Fig. 4, the catalyst loading of $250 \mathrm{mg} \mathrm{L}^{-1}$ could neither inactivate the bacteria nor completely degrade EE2 in the suspension within $240 \mathrm{~min}$. However, with the loading of $500 \mathrm{mg} \mathrm{L}^{-1}$, bacterial inactivation of $7.2 \mathrm{log}$ reduction was achieved after $210 \mathrm{~min}$, and EE2 was degraded below the detection limit in $240 \mathrm{~min}$. While the EE2 degradation was not much affected by the presence of bacterial population, bacterial inactivation was greatly affected by the presence of EE2 in the suspension. The possible reason for this might be the competition for photons and ROS between EE2 and E. coli $^{19}$ rather than that for active sites as a direct contact is not a prerequisite for bacterial inactivation. ${ }^{44}$ Moreover, E. coli is repelled by the negatively charged GO. ${ }^{45}$ Therefore, serious consideration has to be given while treating the water sample with different types of pollutants since optimal loading and treatment time may vary from one system to another, where low loading can cause insufficient generation of ROS, at the same time, more loading can shield the photons.

\section{Changes in the bacterial cells after the photocatalytic treatment}

Bacterial permeability damage (injury). The injured bacterial cell loses its selective permeability, allowing the entry of sodium

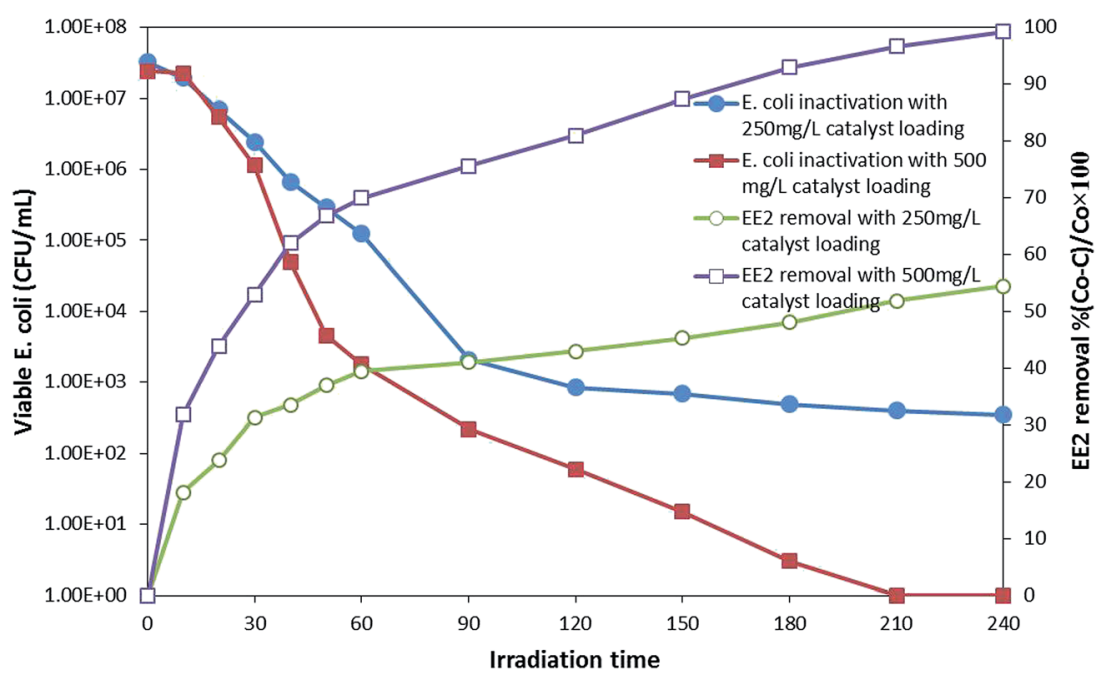

Fig. 4 Simultaneous E. coli inactivation and EE2 degradation in different loadings. 
cholate in the selective LB medium, inhibiting the growth of the bacteria. ${ }^{46}$ The bacteria growing in the selective medium are those with an intact outer membrane; therefore, the difference in the number of bacteria in the non-selective and selective LB media provided the estimate of bacterial injury.

As can be seen in Fig. 5, at $0 \mathrm{~min}$, the total population of bacteria was without any injury; however, after only $10 \mathrm{~min}$ of the photocatalytic treatment, bacterial injury increased to $40 \%$ and then to $88 \%$ and $96 \%$ after 20 and 30 min of the photocatalytic treatment, respectively, in sodium cholate-supplemented LB medium, whereas the bacteria completely lost its cultivability in $40 \mathrm{~min}$, indicating that almost all bacterial permeability was compromised by this time. The slow decline in the total bacterial population compared to that of the non-injured population confirms the recovery of the fraction of the bacterial population that was unable to grow in the selective medium. ${ }^{23}$ Hence, the zone between the total bacteria and non-injured bacteria can be said to represent recoverable, sub-lethally injured bacteria at a particular treatment time. With the increasing treatment time, the recovery of bacteria was reduced, which might be due to intensification of the injuries from sub-lethal to lethal, eventually leading to bacterial inactivation in $60 \mathrm{~min}$.

Scanning electron microscopy analysis of the bacterial morphology. The morphological changes in $E$. coli during the treatment with $\mathrm{ZnFe}_{2} \mathrm{O}_{4}-\mathrm{Ag} / \mathrm{rGO} \mathrm{NC}$ can be observed via scanning electron microscopy (SEM) (Fig. 6). Before the addition of the nanocomposite, rod-shaped $E$. coli having a continuous outer membrane were observed (Fig. 6(a)). As the nanocomposite came in contact with the bacteria, it covered the entire bacteria, as shown in Fig. 6(b). Gradually, over the treatment time, some irregularities on the surface were seen although the damage made underneath was obscure due to the overlying nanocomposites. Fig. 6(c) shows the bacteria covered by the nanocomposites after $30 \mathrm{~min}$ of treatment. By $60 \mathrm{~min}$ of exposure, $E$. coli cells lost the integrity of the outer membrane, revealing a discontinuous and distorted appearance and releasing its intracellular contents. ${ }^{45}$

FTIR spectroscopy of the bacterial cell substances. Cells consist of different structures that are composed of macromolecules such as proteins, carbohydrate, lipids, polyphosphate, and polysaccharides. The functional groups of these macromolecules exert characteristic absorption bands in the FTIR spectrum owing to the vibration in the bonds. Hence, any damage in the cell during the photocatalytic treatment can be examined by the change in the FTIR spectrum before and after the treatment. ${ }^{47,48}$

The FTIR spectra of $E$. coli, before and after photocatalytic treatment, were considerably different (Fig. 7). There was a decrease in the peak intensity and slight shift towards the higher wavenumber in the region between 3700 and $3500 \mathrm{~cm}^{-1}$, which could be assigned to the free $-\mathrm{OH}$ group. ${ }^{49-51}$ Significant disorder was observed in the $3000-2800 \mathrm{~cm}^{-1}$ region, demonstrating that fatty acids of various membrane components were reduced and transformed. ${ }^{50}$ The peaks at 1645 and $1550 \mathrm{~cm}^{-1}$ due to the presence of amide I and amide II bands of proteins and peptides shifted to the lower wavenumbers 1640 and 1548 $\mathrm{cm}^{-1}$, respectively, indicating changes in the protein structures after the treatment. A significant change observed in the 1450$1200 \mathrm{~cm}^{-1}$ region also corresponded to the change in protein and fatty acid. The decrease in the intensity of the peaks at 1238 and $1087 \mathrm{~cm}^{-1}$ after the treatment specifies the destruction of the bacterial membrane phospholipid. ${ }^{48}$ Disappearance of the $881 \mathrm{~cm}^{-1}$ peak signifies breakdown of the glycoside linkages of polysaccharide molecules of the cell membrane. ${ }^{\mathbf{4 9 , 5 0}}$

The changes in the intensities and position of the peaks in the FTIR spectra clearly revealed that the photocatalytic treatment with $\mathrm{ZnFe}_{2} \mathrm{O}_{4}-\mathrm{Ag} / \mathrm{rGO}$ affected the cellular substances containing different macromolecules, leading to the loss of viability and inactivation under visible light irradiation. Bacterial injury, SEM, and FTIR results correspond to each other, signifying that the bacterial inactivation that started from sub-

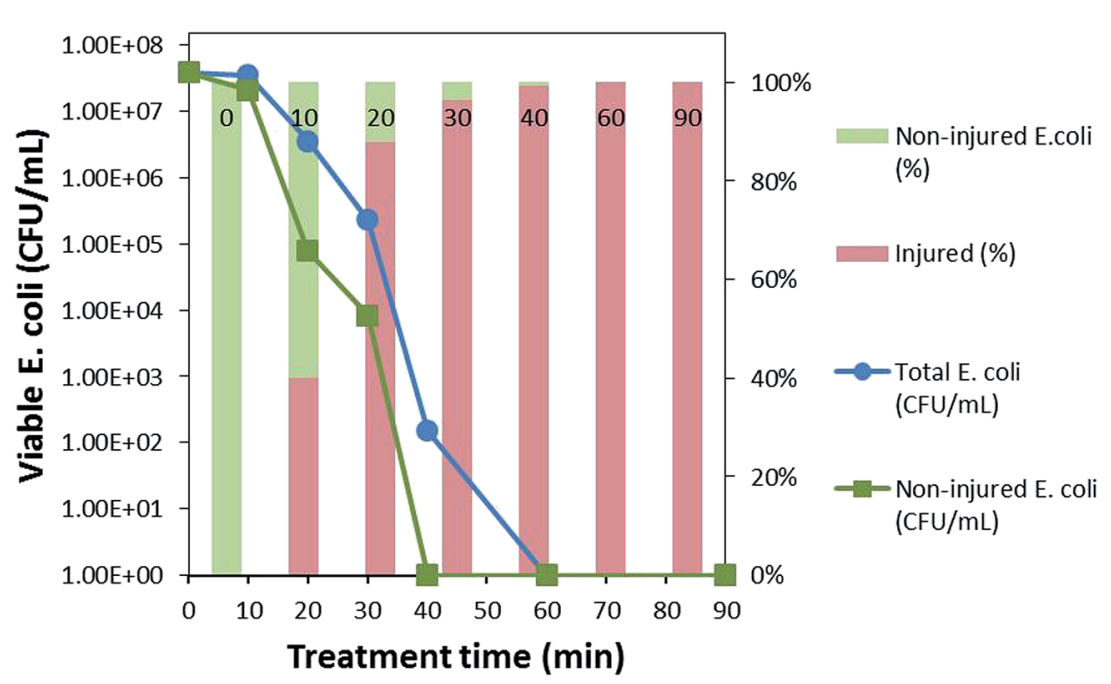

Fig. 5 Bacterial cell density in non-selective and selective LB medium, indicating total and non-injured E. coli, respectively, and cell injury percentage during photocatalytic treatment. 


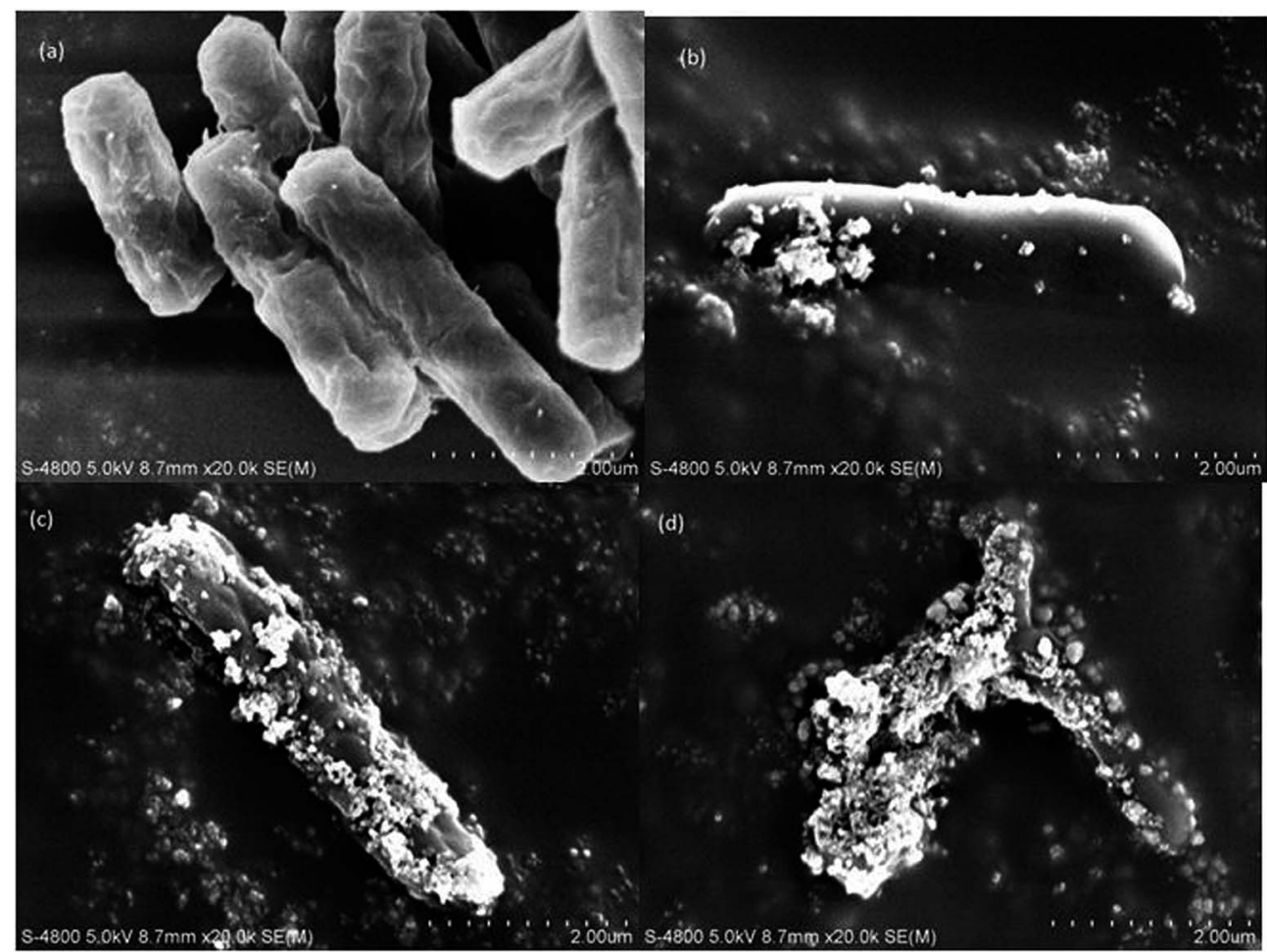

Fig. 6 SEM images of E. coli (a) before the addition of the nanocomposite, at time (b) 0 min, (c) 30 min, and (d) 60 min.

lethal injury gradually turned into lethal, decomposing different components of $E$. coli, leading to its inactivation.

Bacterial enzyme assay. Bacterial cells possess a defense mechanism that consists of different antioxidative enzymes that neutralize the oxidative stress exerted by the ROSs. The oxidative stress experienced by the bacterial cell was investigated by monitoring the enzymatic activity of two main enzymes: superoxide dismutase (SOD) and catalase (CAT). SOD catalyzes the dismutation of the superoxide radical $\mathrm{O}_{2}{ }^{\cdot-}$ to $\mathrm{H}_{2} \mathrm{O}_{2}$ and $\mathrm{O}_{2}$, and catalase catalyzes the conversion of $\mathrm{H}_{2} \mathrm{O}_{2}$ to $\mathrm{O}_{2}$ and $\mathrm{H}_{2} \mathrm{O} .^{25}$ As seen in Fig. 8, the enzyme activity of both SOD and CAT abruptly increased after the treatment in response to the

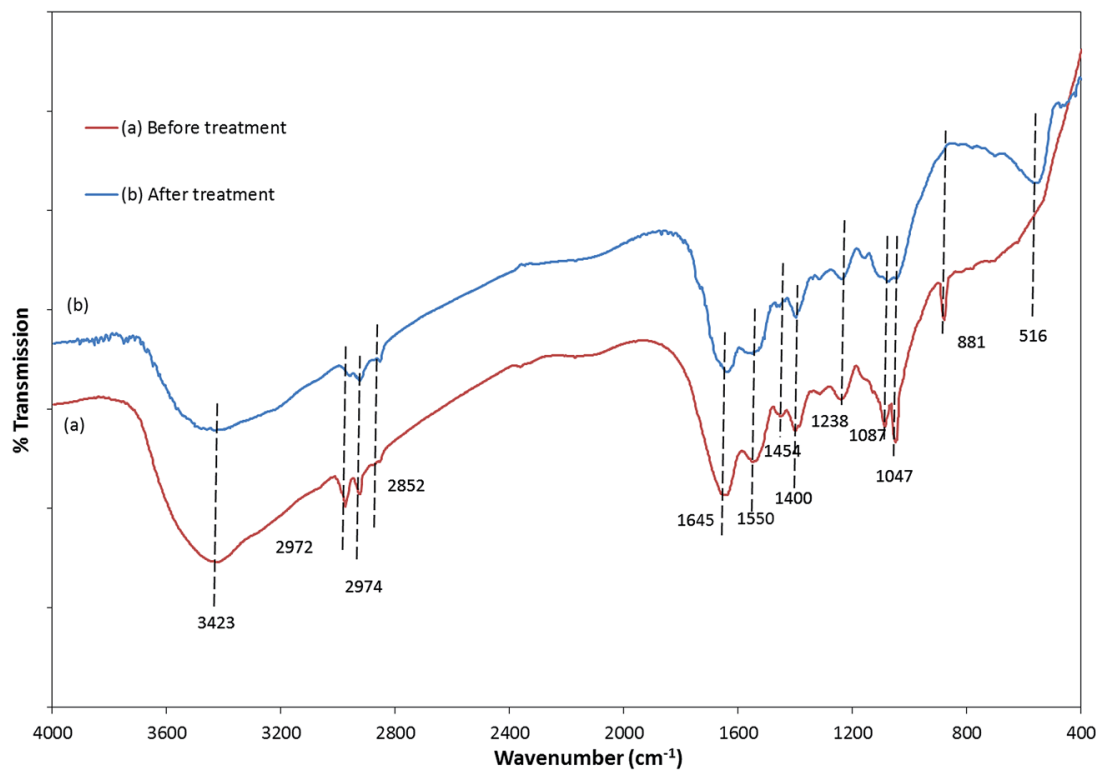

Fig. 7 FTIR spectra of $E$. coli (a) before and (b) after the photocatalytic treatment. 


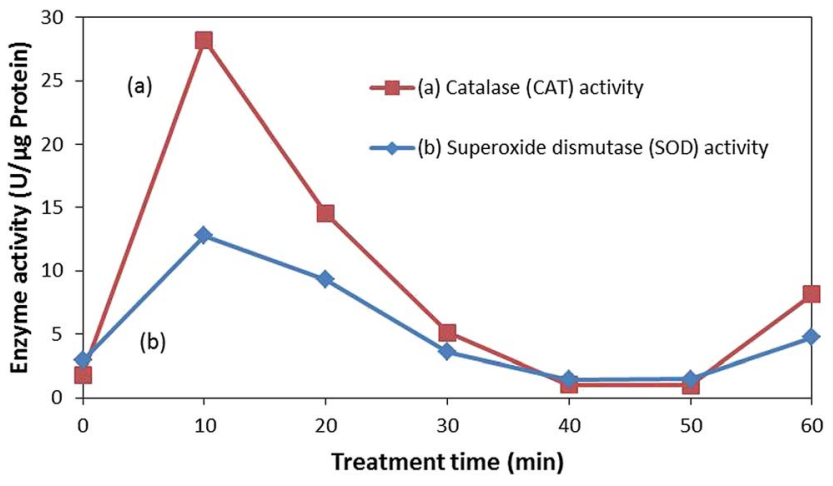

Fig. 8 SOD and CAT activity during the photocatalytic treatment.

suppression of the oxidative stress induced via the photocatalytic treatments. Higher activities of these enzymes indicate more oxidative stress experienced by E. coli from the ROS attack. However, with the prolonged exposure to ROS attack, the defense mechanism gets exhausted and enzymatic activity declines, accelerating the accumulation of the ROSs. ${ }^{52}$ ROS attack can lead to protein fragmentation, release of ions, and generation of protein carbonyl derivatives, which leads to inactivation. ${ }^{47,52}$ Therefore, bacterial inactivation can be said to be caused by the elevated intracellular ROS levels, overwhelming the bacterial defense mechanism, disintegrating the bacterial membrane, and eventually leading to inactivation.

\section{Role of different active species in the photocatalytic treatment}

Identification of the main active species in the photocatalytic reaction is of great importance for understanding the photocatalytic mechanism of the synthesized NCs. The contribution of different active species was analyzed using their scavengers for $E$. coli inactivation and EE2 degradation.

Active species scavenging experiment for bacterial inactivation. As illustrated in Fig. 9(a), as compared to that in the absence of a scavenger, the bacterial inactivation was significantly inhibited via the addition of catalase, scavenging $\mathrm{H}_{2} \mathrm{O}_{2}$ followed by $\mathrm{Cr}(\mathrm{Iv})$, ascorbic acid, isopropanol, and EDTA as scavengers of $\mathrm{e}^{-}, \mathrm{O}_{2}{ }^{--}, \mathrm{OH}^{\cdot}$, and $\mathrm{h}^{+}$, respectively. This implies that $\mathrm{H}_{2} \mathrm{O}_{2}$ plays the most important role in bacterial inactivation as compared to other reactive species. $\mathrm{H}_{2} \mathrm{O}_{2}$ can diffuse into the bulk suspension and across the cell membrane, as reported in an earlier study ${ }^{47}$ In the presence of light, the physiology of the bacterial cells is altered, increasing their sensitivity towards $\mathrm{H}_{2} \mathrm{O}_{2}$ without having to convert it into other radicals and facilitating the bacterial inactivation. ${ }^{53}$

Active species scavenging experiment for EE2 degradation. As shown in Fig. 9(b), after the addition of the scavengers, photocatalytic degradation of EE2 decreased in the order of EDTA $>$ catalase $>\mathrm{K}_{2} \mathrm{Cr}_{2} \mathrm{O}_{4}>$ ascorbic acid $>$ isopropanol, with about $89 \%, 75 \%, 68 \%, 62 \%$, and $40 \%$ degradation, respectively, within 240 minutes. This implied that although all the active species play some role in the degradation of EE2, $\mathrm{OH}^{*}$ being the strongest oxidant play the dominant role, whereas holes have the least effect. The least contribution of holes can be attributed to the low oxidation potential of the holes. ${ }^{54}$
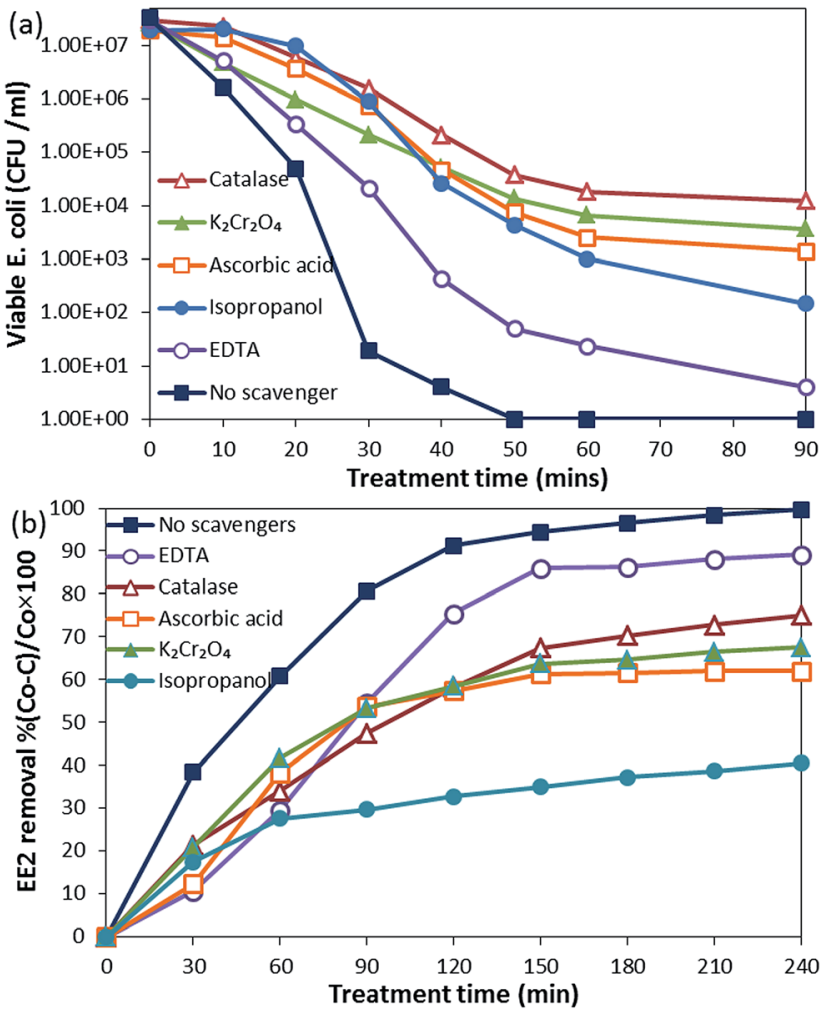

Fig. 9 : ROS scavenger experiments in photocatalytic (a) bacterial inactivation system and (b) degradation of EE2.

Active species scavenging experiments clearly show the difference in the roles played by the active species in bacterial inactivation and EE2 degradation. $\mathrm{H}_{2} \mathrm{O}_{2}$ had the major role in E. coli inactivation, whereas in EE2 degradation, $\mathrm{OH}^{*}$ was important.

\section{Photocatalytic inactivation of Staphylococcus haemolyticus}

The inactivation of Staphylococcus haemolyticus, as the model of Gram-positive bacteria, was also performed to determine its efficacy on Gram-positive bacteria. The SEM image of $S$. haemolyticus during various treatment times and the inactivation curve are shown in Fig. S7. $\uparrow$ The complete inactivation of $S$. haemolyticus was achieved within 90 minutes of visible light irradiation (Fig. S7(d) †). The presence of a cell wall with a thick peptidoglycan layer contributed to longer inactivation time compared to that in Gram-negative E. coli. ${ }^{55}$ However, the composite was able to effectively inactivate the Gram-positive and Gram-negative bacteria. Regardless of the different structure of the bacteria, the inactivation mechanism was similar. ${ }^{56}$

\section{Photocatalytic mechanism}

A plausible reaction mechanism for the high photocatalytic activity of $\mathrm{ZnFe}_{2} \mathrm{O}_{4}-\mathrm{Ag} / \mathrm{rGO}$ was proposed based on the generation of $\mathrm{OH}^{\circ}, \mathrm{O}_{2}{ }^{--}$, and $\mathrm{H}_{2} \mathrm{O}_{2}$. The formation of $\mathrm{O}_{2}{ }^{--}, \mathrm{OH}^{*}$, and $\mathrm{H}_{2} \mathrm{O}_{2}$ was also confirmed by terephthalic acid, NBT, and titanium oxysulphate tests, respectively [Fig. S8-S10†]. $\mathrm{ZnFe}_{2} \mathrm{O}_{4}$ having the band gap of $1.9 \mathrm{eV}$ can be excited by visible light to produce an electron-hole pair $^{57}$ (eqn (1)). The electrons in the valence band 
(VB) move to the conduction band (CB) after the absorption of light. Moreover, Ag NPs were also excited by visible light due to the surface plasmon resonance, generating electrons ${ }^{58,59}$ (eqn (2)). The electrons from $\mathrm{ZnFe}_{2} \mathrm{O}_{4}$ and $\mathrm{Ag}$ were transferred to rGO due to their well-matched band potential. ${ }^{54}$ The photogenerated electron $\left(\mathrm{e}^{-}\right)$in the conduction band $(\mathrm{CB})$ of $\mathrm{ZnFe}_{2} \mathrm{O}_{4}\left(E_{\mathrm{CB}}=-1.54 \mathrm{~V} v\right.$. $\mathrm{NHE})^{57}$ was readily scavenged by the dissolved oxygen to form superoxide anion $\mathrm{O}_{2}{ }^{--}\left(E_{0}=-0.33 \mathrm{~V}\right.$ vs. NHE) (eqn (1)). ${ }^{60}$ Further disproportionation reactions of superoxide anions can lead to the formation of $\mathrm{H}_{2} \mathrm{O}_{2}$ and $\mathrm{OH}^{\bullet}$ (eqn (4)-(7)).

$$
\begin{gathered}
\mathrm{ZnFe}_{2} \mathrm{O}_{4}+h \nu \rightarrow \mathrm{ZnFe}_{2} \mathrm{O}_{4}\left(\mathrm{e}^{-}+\mathrm{h}^{+}\right) \\
\mathrm{Ag}+h \nu \rightarrow \mathrm{Ag}\left(\mathrm{e}^{-}\right) \\
\mathrm{ZnFe}_{2} \mathrm{O}_{4}\left(\mathrm{e}^{-}\right) \rightarrow \mathrm{Ag}\left(\mathrm{e}^{-}\right) \rightarrow \mathrm{rGO}\left(\mathrm{e}^{-}\right) \\
\mathrm{O}_{2}+\mathrm{e}^{-} \rightarrow \mathrm{O}_{2}^{\cdot-} \\
\mathrm{O}_{2}^{\cdot-}+\mathrm{O}_{2}^{\cdot-}+2 \mathrm{H}^{+} \rightarrow \mathrm{H}_{2} \mathrm{O}_{2}+\mathrm{O}_{2} \\
\mathrm{H}_{2} \mathrm{O}_{2}+\mathrm{e}^{-} \rightarrow \mathrm{OH}^{\cdot}+\mathrm{OH}^{-} \\
\mathrm{H}_{2} \mathrm{O}_{2}+\mathrm{O}_{2}^{\cdot-} \rightarrow \mathrm{OH}^{\cdot}+\mathrm{OH}^{-}+\mathrm{O}_{2}
\end{gathered}
$$

The ROS generation possibly follows the reductive mechanism involving dissolved oxygen and photogenerated electrons rather than oxidation by photogenerated holes as they do not possess suitable reduction potential to generate a $\mathrm{OH}^{*}$ radical. ${ }^{61}$ The valence band of $\mathrm{ZnFe}_{2} \mathrm{O}_{4}\left(E_{\mathrm{VB}}=0.38 \mathrm{~V} v s \text {. NHE }\right)^{57}$ is more negative than the water reduction potential to directly oxidize $\mathrm{OH}^{-}(E=1.99 \mathrm{eV})$ or $\mathrm{H}_{2} \mathrm{O}(E=2.8 \mathrm{~V} v s$. NHE $)$ to $\mathrm{OH}^{*}$. However, the photogenerated holes $\mathrm{h}^{+}$can directly be involved in the oxidation of EE2 and bacterial inactivation. ${ }^{53}$ This corresponds with the active species scavenging mechanism experiments. Despite the low oxidation potential of $\mathrm{ZnFe}_{2} \mathrm{O}_{4}$, the efficient electron transfer from $\mathrm{ZnFe}_{2} \mathrm{O}_{4}$ to rGO and $\mathrm{Ag}$ NPs in the composite prolongs their lifetime, suppresses the unfavorable recombination, and enhances the photocatalytic activity of the $\mathrm{ZnFe}_{2} \mathrm{O}_{4}-\mathrm{Ag} / \mathrm{rGO}$ nanocomposite.

\section{Conclusions}

The present study demonstrated that $\mathrm{ZnFe}_{2} \mathrm{O}_{4}-\mathrm{Ag} / \mathrm{rGO}$ exhibited efficient photocatalytic performance during $E$. coli inactivation and EE2 degradation. A reductive mechanism initiated by the photogenerated electrons was proposed for ROS generation owing to the low oxidation potential of $\mathrm{ZnFe}_{2} \mathrm{O}_{4}$. The results obtained from the simultaneous photocatalytic process indicated that both the optical loading and treatment time increased for bacterial inactivation in the presence of EE2. Further, the main ROS for bacterial inactivation was $\mathrm{H}_{2} \mathrm{O}_{2}$, whereas $\mathrm{OH}^{*}$ played the major role for EE2 degradation. Hence, the study highlights the necessity to re-examine the test design for the assessment of antibacterial effects under real conditions where many emerging pollutants might also be present along with microbial population since the catalyst loading, treatment time, and role of active species vary from one component to another.

\section{Acknowledgements}

This study was supported by the National Natural Science Foundation of China (grant 51322901) and National Science Funds for Creative Research Groups of China (grant 51421006).

\section{References}

1 WHO, Drinking-water Fact sheet, http:/www.who.int/ mediacentre/factsheets/fs391/en/, accessed 29 January 2017.

2 J. O. Tijani, O. O. Fatoba, O. O. Babajide and L. F. Petrik, Environ. Chem. Lett., 2016, 14, 27-49.

3 K. Noguera-Oviedo and D. S. Aga, J. Hazard. Mater., 2016, 316, 242-251.

4 M. Martínez-Sales, F. García-Ximénez and F. J. Espinós, Zygote, 2016, 24, 563-567.

5 A. Zamyadi, L. Ho, H. Bustamante and M. Prévost, Water Res., 2012, 46, 1524-1535.

6 J. D. Plummer and J. K. Edzwald, Water Sci. Technol., 1998, 37, 49-55.

7 S. D. Richardson, TrAC, Trends Anal. Chem., 2003, 22, 666684.

8 K. G. McGuigan, R. M. Conroy, H.-J. Mosler, M. du Preez, E. Ubomba-Jaswa and P. Fernandez-Ibañez, J. Hazard. Mater., 2012, 235, 29-46.

9 E. Ubomba-Jaswa, C. Navntoft, M. I. Polo-López, P. Fernandez-Ibáñez and K. G. McGuigan, Photochem. Photobiol. Sci., 2009, 8, 587.

10 M. N. Chong, B. Jin, C. W. K. Chow and C. Saint, Water Res., 2010, 44, 2997-3027.

11 A. Di, E. García-lópez, G. Marcì and L. Palmisano, J. Hazard. Mater., 2012, 211-212, 3-29.

12 K. Sorathiya, B. Mishra, A. Kalarikkal, K. P. Reddy, C. S. Gopinath and D. Khushalani, Sci. Rep., 2016, 6, 35075.

13 M. Bundschuh, F. Seitz, R. R. Rosenfeldt and R. Schulz, Freshwater Biol., 2016, 61, 2185-2196.

14 D. Venieri, A. Fraggedaki, M. Kostadima, E. Chatzisymeon, V. Binas, A. Zachopoulos, G. Kiriakidis and D. Mantzavinos, Appl. Catal., B, 2014, 154, 93-101.

15 M. Ni, M. K. H. Leung, D. Y. C. Leung and K. Sumathy, Renewable Sustainable Energy Rev., 2007, 11, 401-425.

16 K. Tahir, A. Ahmad, B. Li, S. Nazir, A. U. Khan, T. Nasir, Z. U. H. Khan, R. Naz and M. Raza, J. Photochem. Photobiol., B, 2016, 162, 189-198.

17 T. W. Ng, L. Zhang, J. Liu, G. Huang, W. Wang and P. K. Wong, Water Res., 2016, 90, 111-118.

18 K. K. Philippe, R. Timmers, R. van Grieken and J. Marugan, Ind. Eng. Chem. Res., 2016, 55, 2952-2958.

19 C. Pablos, R. van Grieken, J. Marugán and A. Muñoz, Water Sci. Technol., 2013, 68(5), 999-1003, DOI: 10.2166/ wst.2013.307.

20 N. Khadgi, Y. Li, A. R. Upreti, C. Zhang, W. Zhang, Y. Wang and D. Wang, Photochem. Photobiol., 2016, 92, 238-246.

21 X. Xu, A. K. Azad and J. T. S. Irvine, Catal. Today, 2013, 199, 22-26.

22 Y. Yoon, P. Westerhoff, S. A. Snyder and M. Esparza, HPLCfluorescence detection and adsorption of bisphenol A, 17 $\beta$ - 
estradiol, and $17 \alpha$-ethynyl estradiol on powdered activated carbon, 2003, vol. 37.

23 P. S. M. Dunlop, M. Ciavola, L. Rizzo, D. A. McDowell and J. A. Byrne, Catal. Today, 2015, 240, 55-60.

24 M. M. Bradford, Anal. Biochem., 1976, 72, 248-254.

25 B. Xia, B. Chen, X. Sun, K. Qu, F. Ma and M. Du, Sci. Total Environ., 2015, 508, 525-533.

26 B. F. Machado and P. Serp, Catal. Sci. Technol., 2012, 2, 5475.

27 H. W. Tien, Y. L. Huang, S. Y. Yang, J. Y. Wang and C. C. M. Ma, Carbon, 2011, 49, 1550-1560.

28 K. Gotoh, T. Kinumoto, E. Fujii, A. Yamamoto, H. Hashimoto, T. Ohkubo, A. Itadani, Y. Kuroda and H. Ishida, Carbon, 2011, 49, 1118-1125.

29 X. Cao, L. Gu, X. Lan, C. Zhao, D. Yao and W. Sheng, Mater. Chem. Phys., 2007, 106, 175-180.

30 Q. Huang, J. Wang, W. Wei, Q. Yan, C. Wu and X. Zhu, J. Hazard. Mater., 2015, 283, 123-130.

31 H. Wang, X. Yuan, Y. Wu, H. Huang, X. Peng, G. Zeng, H. Zhong, J. Liang and M. Ren, Adv. Colloid Interface Sci., 2013, 195, 19-40.

32 S. Liu, J. Tian, L. Wang and X. Sun, J. Nanopart. Res., 2011, 13, 4539-4548.

33 L. Sun, R. Shao, L. Tang and Z. Chen, J. Alloys Compd., 2013, 564, 55-62.

34 X. Li, Y. Hou, Q. Zhao and L. Wang, J. Colloid Interface Sci., 2011, 358, 102-108.

35 Y. Hou, X. Li, Q. Zhao and G. Chen, Appl. Catal., B, 2013, 142, $80-88$.

36 P. K. Sudeep and P. V Kamat, Chem. Mater., 2005, 17, 54045410.

37 Y. Liu, S. Wei and W. Gao, J. Hazard. Mater., 2015, 287, 5968.

38 L. V. Zhukova, ACS Appl. Mater. Interfaces, 2015, 7, 2719727205.

39 C.-H. Deng, J.-L. Gong, G.-M. Zeng, Y. Jiang, C. Zhang, H.-Y. Liu and S.-Y. Huan, Chem. Eng. J., 2016, 284, 41-53.

40 S. M. Zacarías, M. L. Satuf, M. C. Vaccari and O. M. Alfano, Chem. Eng. J., 2015, 266, 133-140.

41 J. Xie, Q. Wu and D. Zhao, Carbon, 2012, 50, 800-807.

42 World Health Organization (WHO), Guidelines for drinkingwater quality, fourth edition incorporating the first addendum, World Health Organization, 2017.

43 L. Caballero, K. A. Whitehead, N. S. Allen and J. Verran, J. Photochem. Photobiol., A, 2009, 202, 92-98.
44 D. Wu, T. An, G. Li, W. Wang, Y. Cai, H. Y. Yip, H. Zhao and P. K. Wong, Appl. Surf. Sci., 2015, 358, 137-145.

45 S. Pigeot-Rémy, F. Simonet, D. Atlan, J. C. Lazzaroni and C. Guillard, Water Res., 2012, 46, 3208-3218.

46 S. Pigeot-Rémy, F. Simonet, E. Errazuriz-Cerda, J. C. Lazzaroni, D. Atlan and C. Guillard, Appl. Catal., B, 2011, 104, 390-398.

47 H. Sun, G. Li, X. Nie, H. Shi, P. Wong, H. Zhao and T. An, Environ. Sci. Technol., 2014, 48, 9412-9419.

48 J. J. Ojeda, M. E. Romero-González, R. T. Bachmann, R. G. J. Edyvean and S. A. Banwart, Langmuir, 2008, 24, 4032-4040.

49 G. Xiao, X. Zhang, W. Zhang, S. Zhang, H. Su and T. Tan, Appl. Catal., B, 2015, 170, 255-262.

50 B. Ramalingam, T. Parandhaman and S. K. Das, ACS Appl. Mater. Interfaces, 2016, 8, 4963-4976.

51 J. Romero-Mangado, D. Nordlund, F. Soberon, G. Deane, K. Maughan, S. Sainio, G. Singh, S. Daniels, I. T. Saunders, D. Loftus, M. Meyyappan, J. Koehne and R. P. Gandhiraman, Biointerphases, 2016, 11, 11009.

52 Y. Shi, S. Jiang, K. Zhou, C. Bao, B. Yu, X. Qian, B. Wang, N. Hong, P. Wen, Z. Gui, Y. Hu and R. K. K. Yuen, Environ. Sci. Technol., 2013, 47, 8724-8732.

53 T. W. Ng, T. An, G. Li, W. K. Ho, H. Y. Yip, H. Zhao and P. K. Wong, J. Photochem. Photobiol., B, 2015, 149, 164-171.

54 H. G. Oliveira, L. H. Ferreira, R. Bertazzoli and C. Longo, Water Res., 2015, 72, 305-314.

55 S. P. Tallósy, L. Janovák, E. Nagy, Á. Deák, Á. Juhász, E. Csapó, N. Buzás and I. Dékány, Appl. Surf. Sci., 2016, 371, 139-150.

56 H. A. Foster, I. B. Ditta, S. Varghese and A. Steele, Appl. Microbiol. Biotechnol., 2011, 90, 1847-1868.

57 S. Boumaza, A. Boudjemaa, A. Bouguelia, R. Bouarab and M. Trari, Appl. Energy, 2010, 87, 2230-2236.

58 B. J. Wiley, S. H. Im, Z.-Y. Li, J. McLellan, A. Siekkinen and Y. Xia, J. Phys. Chem. B, 2006, 110, 15666-15675.

59 J. K. Nayak, P. Parhi and R. Jha, J. Phys. D: Appl. Phys., 2016, 49, 285101.

60 P. M. Wood, Biochem. J., 1988, 253, 287-289.

61 M. Pelaez, N. T. Nolan, S. C. Pillai, M. K. Seery, P. Falaras, A. G. Kontos, P. S. M. Dunlop, J. W. J. Hamilton, J. A. Byrne, K. O'Shea, M. H. Entezari and D. D. Dionysiou, Appl. Catal., B, 2012, 125, 331-349.

62 W. S. Hummers and R. E. Offeman, J. Am. Chem. Soc., 1958, 80, 1339-1339. 